\title{
INTERNATIONAL EXPERIENCE AND THE PERFORMANCE OF SCANDINAVIAN FIRMS IN CHINA
}

\author{
by \\ Johan Carlsson, Axel Nordegren \& Fredrik Sjöholm \\ Working Paper No 188 \\ February 2004
}

Postal address: P.O. Box 6501, S-113 83 Stockholm, Sweden. Office address: Sveavägen 65

Telephone: +4687369360 Telefax: +468313017 E-mail: japan@hhs.se Internet:

http://www.hhs.se/eijs 


\title{
International Experience and the Performance of \\ Scandinavian Firms in China
}

\author{
Johan Carlsson \\ Axel Nordegren \\ Fredrik Sjöholm* \\ Stockholm School of Economics
}

\begin{abstract}
Western firms locating in China face a business environment that differs from their home country environment. The differences increase uncertainties and are negative for economic performance. However, firms may differ in their ability to overcome the difficulties, depending on their previous experience. In particular, firms with experience from regions similar to China might do comparably well. We conduct a survey of Scandinavian firms with subsidiaries in China to examine their economic performance. Our results show that subsidiaries in China perform better if the firms have subsidiaries in Hong Kong, Taiwan, or Singapore. In addition, the length of subsidiaries' operation in China, and the experience from foreign countries outside of Greater China, are also positively affecting the subsidiaries' economic performance.
\end{abstract}

Keywords: FDI; Firms; Experience; China; Scandinavia

JEL classification: F20; F23; M20

\footnotetext{
* Corresponding author: Stockholm School of Economics, Sveav. 65, P.O. Box 6501, S-113 83 Stockholm, Sweden, email - japfs@hhs.se.
} 


\section{Introduction ${ }^{\#}$}

China attracts large inflows of foreign multinational companies. Most of these firms come from other regions in Greater China: Hong Kong, Singapore, and Taiwan. Few would doubt that such firms have a major advantage over its Western competitors; they possess the cultural competence; they have the business contacts; they know the language (Luo, 1999). Western firms in China face a business environment that differs from their home country conditions, but there are several ways for the firms to learn about the Chinese market. The most obvious one is by being present in China, and firms with a relatively long history in China will presumably have acquired a relatively good knowledge of the Chinese market. Moreover, it is likely that a long experience of foreign operations, and experience of operations in many different countries, will enhance the firm's ability to learn about a new market. Hence, experience from foreign operations in general will presumably facilitate leaning about the Chinese market. Finally, it is possible that firms with experience of markets that are relatively similar to the Chinese market, markets that are on a short psychic distance from China, will find it easier to operate in China compared to firms with no such experience.

This paper examines the performance of Scandinavian firms in China. ${ }^{1}$ We ask the question if a subsidiary's performance in China can be related to various types of experience. In particular, we focus on experience from markets that are on a short psychic distance from China by examining if experience from Hong Kong, Taiwan, and Singapore leads to comparatively better performance in China.

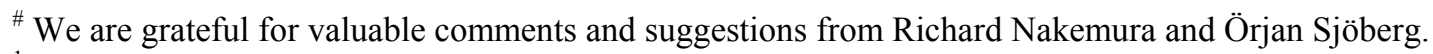

${ }^{1}$ Scandinavia consists of Denmark, Norway, and Sweden.
} 
The literature on market knowledge and the internationalisation process of the firm tends to focus on the process in general and not on specific markets. ${ }^{2} \mathrm{We}$ contribute to the literature by applying a general theoretical framework on internationalisation, on the firm's performance in a particular foreign market. More importantly, previous research has assessed the relation between experience and performance mainly by focusing on differences between the firm's home market and host markets for its investments. Our approach is different as we try to assess the significance of prior regional presence on the performance. Hence, we are studying the importance of market similarities by focusing on the Greater China region.

The paper starts with a description of relevant theories and their implications for our stated question. We continue with a description of the survey, consisting of two questionnaires distributed to Chinese subsidiaries and parent companies respectively. A brief presentation of the data and the construction of various variables follow. Subsequently, we analyse the data and discuss our findings. The paper ends with concluding remarks.

\section{Conceptual framework}

Theories on the internalisation of the firm are primarily concerned by where firms locate, but the theories can also serve as a framework for evaluating firms' performances in a specific market. There are uncertainties involved for firms entering new markets, and firms will try to gain knowledge about new markets to minimize these uncertainties. This typically includes knowledge about foreign business cultures and customs. Carlson (1975) and Johanson and Vahlne (1990), among others, discuss

\footnotetext{
${ }^{2}$ See e.g. Aharoni (1966), Carlson (1975), Vahlne and Wiedersheim-Paul (1977), Cavusgil (1984), Hörnell and Vahlne (1986), Johanson and Mattsson (1988), Forsgren (1989), and Bell (1996).
} 
the issue in terms of networks; market knowledge is knowledge about how the network works, that is, how relations to different actors on the market are established and developed, how coordination of activities takes place, and how the work is divided within the network.

Johanson and Vahlne (1977:28) argue that the relevant market knowledge can be divided into objective knowledge and two types of experiential knowledge: general knowledge and market-specific knowledge. Objective knowledge can be learned by studying a new market before entering it, and includes knowledge of market size, customer purchasing power, laws, and regulations. Objective knowledge is relatively easy to acquire and should not be of any crucial importance for the relative performance of firms within a market.

General knowledge concerns marketing methods, formalities connected with purchases, sales, payments, employees, and common characteristics of certain types of customers and suppliers, irrespective of their geographic location. This type of experiential market knowledge is acquired from international operations in general and can be transferred from one country to another (Johanson and Vahlne, 1990; Kimberly and Rottman, 1987; Black and Mendenhall, 1991). Hence, general knowledge is knowledge about how to handle international operations, but it is not market-specific. The longer the firm's experience of international operations, the more general knowledge has it presumably acquired.

Finally, experiential market-specific knowledge is knowledge about the specific market and its characteristics: business climate, culture, structure of the market system, and knowledge about individual customers. The experiential market-specific knowledge is critical in the firm's internationalisation (Penrose, 1959:53-56). It cannot be acquired as easily as objective knowledge, and it concerns the 
characteristics of the specific foreign market rather than international operations in general.

Firms' uncertainty when they enter a new market is to a high extent caused by lack of experiential market-specific knowledge (Johanson and Vahlne, 1977:26). Experiential market-specific knowledge is accumulated once the subsidiary is operating on the market. This does not mean that all firms acquire the market-specific knowledge at a similar pace; market-specific knowledge will not be automatically accumulated but affected by firm-characteristics (March and Olsen, 1976). In other words, even though all firms face a learning curve when they enter a new market, the individual learning curves may have different shapes. According to Carlson (1975:9), some firms learn faster than others because of earlier activities. He argues that the more different the foreign market is compared to the firm's current markets, the more difficult it is for the firm to gain experiential market-specific knowledge. Firms usually have better knowledge about opportunities and business alternatives in its immediate surroundings than of markets located far away from the firm. The ability to gain experiential market knowledge will therefore decrease with the "degree of foreignness", commonly referred to as the psychic distance (Vahlne and Wiedersheim, 1977). Hence, it takes long time to gather and interpret market information from markets that are on a long psychic distance from the firm's current markets.

Psychic distance is not only determined by similarities and differences between the market in question and the home country of the firm. Firms may learn from experiences in one foreign market that might later by valuable when subsidiaries are 
established on additional foreign markets. ${ }^{3}$ The difficulty of establishing linkages with foreign networks in a new market depends on the characteristics of the networks (Chen, 1998:7). The more similar the networks are in different countries, the easier it is to create linkages in new markets (Johanson and Vahlne, 1990). A network similarity between countries is therefore a concept synonymous to psychic distance.

The importance of psychic distance for the internationalisation process has been questioned in several studies (e.g. Hedlund and Kverneland, 1984; Hood and Young, 1983; Petersen and Pedersen, 1997). It seems that countries are becoming more homogenous, which together with progress in information technologies suggest that psychic distance is important primarily in the early phase of a firm's internalisation (Hörnell and Vahlne, 1986; Björkman and Eklund, 1996). It is also important to point out, again, that our focus is the effect of psychic distance on the performance of firms in a particular market, and not on the decision whether or no to enter this market.

\subsection{Psychic distance in Greater China}

The discussion above tells us that firms obtaining experiential market knowledge faster than others will perform better within a specific market. The theories also tell us that firms will obtain experiential market knowledge faster if the perceived psychic distance is short, and that the distance is comparably short for firms that have prior experiences from markets that are similar to the new market.

In the case of China, such experience might be achieved from presence in Hong Kong, Singapore, and Taiwan. In other words, the psychic distance between China and Hong Kong, Singapore, and Taiwan is presumably shorter than between China

\footnotetext{
${ }^{3}$ It might even be the subsidiary that take the initiative to enter new foreign markets (Sharma, 1991:102)
} 
and other countries. For instance, the Chinese language is to a large extent shared by all regions in Greater China with mandarin Chinese as the lingua franca. The language similarity is greatest between Taiwan and China; mandarin Chinese is the language used in business and official contexts in both areas, and to a high extent also in everyday conversations. A different dialect of Chinese is used in Hong Kong, but the general knowledge of mandarin Chinese is widespread and the written language is similar. Singapore has four official languages and it is English, rather than mandarin Chinese, that is the main business language. However, mandarin Chinese is still known by a majority of the business community and is used as the language of communication between Singapore and China.

There are also strong cultural similarities between the regions in Greater China. Luo (1999) shows that firms from Greater China are better than firms from other countries in interpreting and understanding information on the Chinese market. Luo argues that the explanation is substantial similarities in social, historical, and cultural backgrounds. The similarities affect, for example, demand conditions, consumer behaviour, and work ethics. Luo also emphasizes the importance of ethnical ties and guanxi in all the regions of Greater China. Guanxi refers to the concept of drawing on connections or networks in order to secure favours in personal and business relations. It connects millions of Chinese firms into a social- and business web. These connections are considered to play a fundamental role in the Chinese community, and it is widely recognized that guanxi is a key determinant of firm performance. Family ties are by far the most fundamental connections. Locality, kinship, friendship and collegiality are other important guanxi factors. 


\subsection{Implications of theory}

From the theoretical discussion above, we would expect that subsidiaries of Scandinavian firms with previous experience from Hong Kong, Taiwan, or Singapore perform better in China than subsidiaries of firms without such experience. This expectation is based on the assumption that experiential market-specific knowledge is an important factor for lowering uncertainty, and therefore important for a firm's performance. Moreover, theory states that firms with experience from countries and regions on a small psychic distance to the specific foreign market will gain experiential market-specific knowledge quicker than firms without such experience. Finally, it has been shown that the psychic distance between China on the one hand and Hong Kong, Taiwan, and Singapore on the other, is relatively short.

Our main hypothesis is that subsidiaries of Scandinavian firms in China perform better if the firms have subsidiaries in Hong Kong, Taiwan, and Singapore. In addition, we will examine if the length of operation in China, and the experience from foreign countries outside of Greater China, will affect the subsidiaries' performance.

\section{Data and variables}

\subsection{Data collection}

We use data at both firm and subsidiary level to examine the issues at hand. Our survey was divided into two questionnaires:

A fact-finding questionnaire (Q1) regarding the internationalisation process of the firm directed to head office personnel in the Scandinavian home country (see Questionnaire 1 in the appendix). 
An evaluative questionnaire $(\mathrm{Q} 2)$ regarding subsidiary-specific information directed to managers of specific subsidiaries in China (see Questionnaire 2 in the appendix).

The target population of the two questionnaires differs and needs to be defined separately. When defining the target population of Q1, we argued that Scandinavian firms have a similar business culture and thus face roughly the same obstacles and benefits on international markets. Hence, we only include firms with headquarters in Scandinavia and by the same logic do not conduct any stratified analyses of the Scandinavian countries. Because of the uncontroversial fact-finding character of Q1, we did not specify any preferences of respondents within the firm.

For Q2, we included establishments that are subsidiaries from the target population. Because of the subjective evaluation of the subsidiary's activities, it was required that the respondents were company staff on a managerial level.

To obtain our sample of Scandinavian subsidiaries in China we used the most recent catalogues of firms established in China provided by the Swedish Trade Council (2002; 2003b), Royal Danish Embassy in Beijing (2003), and Norwegian Trade Council (2003) as our sampling frame. Because of the small target population, we included all firms within our frame.

In August 2003, we administered Q2 in two modes; electronic surveys distributed via e-mail, and mail surveys sent to postal addresses in cases where no email address was available. For both questionnaires, we sent out two reminders if there was no response. The first reminder was distributed one week after the original distribution and the second reminder after two additional weeks. After excluding a few firms that were no longer present in China or that no longer were Scandinavian 
subsidiaries, our remaining census consisted of 224 subsidiaries and 171

Scandinavian parent companies, including 11 firms and subsidiaries that expressed a wish not to participate in the survey.

We received 66 completed questionnaires (Q1 and Q2). A survey response rate of $29 \%$ will bias the results if the respondents are not representative of the target population. A common misrepresentation is that respondents with a non-satisfactory performance are more reluctant to respond to questionnaires regarding such issues. However, when comparing performance data with surveys conducted by the Swedish and Norwegian Trade Councils, the results seem to be similar in terms of firms' performance (Swedish Trade Council, 2003b; Norwegian Trade Council, 1998). Moreover, the purpose of our thesis is not to make inferences or conclusions about performance per se, but to make comparisons of subsidiaries with different experiences. The possibility of a bias towards successful subsidiaries is not likely to distort such a comparison.

Another form of non-sampling errors is derived from the respondents, who may provide inaccurate answers because of fatigue, boredom, faulty recall, question format, question content (inability errors), or because they intentionally misreport their answers (unwillingness errors) (Malhotra, 1999:275). We tried to minimize response errors by the following procedures:

A pre-testing of Q2 in order to identify and eliminate problems. With the received feedback we altered wording to some questions to enhance clarity.

We directed Q2 to managers to ensure that respondents were informed. 
Performance evaluation questions appear on different places in Q2 in order to avoid order bias. The responses were highly correlated, which is an indication of limited response errors.

Q2 was answered easily by tick-in-the-box clicks to avoid a lengthy process and thus avoid careless answers due to fatigue and boredom. We emphasized the confidentiality of individual responses. Unwillingness errors might occur and give rise to too positive evaluations if the survey reply is shared with the parent company, or if respondents had doubts about the confidentiality of the individual responses.

It is difficult to evaluate the extent of response errors. Comparisons with previous surveys and examining internal correlations are ad hoc measures for such evaluations. As previously said, our survey seems to show similar results on performance as previous studies. Moreover, questions in Q2 that by logic should be correlated, that is, questions 15 and 16; questions 17 and 18; and the three performance questions 9, 11, and 25, are indeed highly correlated (Table A1 in the appendix), which at least indicates that there are no obvious response errors.

\subsection{Performance - the dependent variable}

Figures on firms' profits, output, or value added are often used to measure performance. One problem is that such figures are affected by transfer pricing, and by differences between firms' handling of royalties, management fees, and their accounting standards (Buckley, 1996:162). Furthermore, presence in a market may have positive effects that do not necessarily materialize in the subsidiary's income statement. A firm can, for instance, benefit from gaining insights and experience in 
research and development or other strategic functions. Presence may also be motivated as a part of an overall marketing strategy or as an option for business opportunities that may arise later on, objectives that all might run contrary to shortrun profit-maximizitation.

We choose to avoid the difficulties above by letting managers evaluate their own subsidiary's performance. An additional benefit with this approach is that surveys with subjective performance questions tend to generate higher response rates. On the negative side, by applying a subjective performance measure, the survey is more exposed to respondent errors.

As seen in table 1, we measure performance by asking three questions: the perceived success of the subsidiary, the perceived contentment of the parent company with the subsidiary's performance, and the overall satisfaction with performance (questions 9; 11; and 25 in Q2). The three questions are added and divided by three to construct the performance variable (PERFORM).

Table 1 here.

\subsection{Experience - the explanatory variables}

We assume that experience leads to market knowledge and that market knowledge follows a learning curve by using a logarithmic function. The logarithmic function shares the characteristics of the learning curve's increasing benefits of experience at a diminishing rate. It also has the plausible effect of estimating the first year as zero 
$(\operatorname{LOG}[1]=0)$ and thus roughly capturing the slow start of benefits in the learning curve. ${ }^{4}$

GCREXP is our main explanatory variable, and measures accumulated experience from Hong Kong, Taiwan, and Singapore, attaching equal weights to the three regions. It is measured in years before start-up of the first subsidiary in China. The variable is based on questions 5, 8, 9, and 10 in Q1.

Market-specific experience is defined as the number of years with subsidiaries in China. The variable (TIMING) is based on question 5 in Q1.

We include two variables on general experience. Firstly, a variable measured by the number of countries the firm had a subsidiary in before the start-up of the first subsidiary in China. The variable (NRCOUNT) is based on question 7 in Q1. Secondly, a variable constructed as the number of years the firm had a subsidiary abroad before the start-up of the first subsidiary in China. The variable (INTYEAR) is based on questions 3 and 5 in Q1.

Besides our different variables on experience, we also include a number of control variables: the ownership form (ENTMODE); experience of individuals in the firm (INDEXP); industry (MANUFACT); type of activity (PROD, RD, and MS); output markets (MARKET1 and MARKET2); output diversification (DIVERSE); and competition (COMP1 and COMP2). All included control variables have been suggested in previous literature to affect performance. ${ }^{5}$

\subsection{Descriptive statistics}

The subsidiaries reported an average performance level of 5.1, on a scale from 1 to 7 and where a high figure represents a good performance. Hence, a majority of the

\footnotetext{
${ }^{4}$ We also adjust the undefined logarithm of zero to zero (LOG $[0]=0$ ).
} 
respondents consider their subsidiaries to be successful. Looking at the different performance measures separately in figure 1, we see that the answers to question 9 and 25 are similar, both with an average on 5.2, showing that the subsidiaries' managers perceive their companies to be successful, and that they are satisfied with company performance. Moreover, 56 percent of the respondents answered that their subsidiary perform better than expected and 20 percent that they perform worse than expected prior to start-up (question 11). The average figure of 4.8 (question 11) is significantly lower than 5.2 (questions 9 and 25), which suggests that expectations have lowered since the firms started their operations in China.

Figure 1 here.

The general picture from our survey, that Scandinavian subsidiaries in China are performing well, is supported by the fact that 76 percent of the respondents had positive return on equity in 2002 (not shown). Moreover, about 75 percent claim that they never before had such a high return on equity, high level of sales and high number of employees.

The firms in our sample varies substantially in their international experience prior to their establishment in China: 53 percent of the firms had earlier experiences from Hong Kong, Singapore, or Taiwan, with a median of 35 accumulated years of presence in those markets. Moreover, 44 percent of the firms had prior experiences from Hong Kong, followed by Singapore with 39 and Taiwan with 29 percent respectively.

\footnotetext{
${ }^{5}$ Se for instance Luo (1998) on entry mode, type of activities and product diversification; Nonaka et al (1996) on individuals' experience; Vahlne and Nordström (1993:531) on industry effects; and Bell (1996) on markets and competition.
} 
The firms had on average subsidiaries in 15 countries before they entered the Chinese market and had 40 years of experience of international subsidiaries. The firms with most international experience were established in over 100 countries and with over 100 years experience of outward FDI, while other firms did not have any international experience at all before entering China. The first firm started its subsidiary in China in 1965. The median firm, though, did not start its operations until 1995. The number of firms with subsidiaries in China increases mainly after 1991.

Our last measure on experience refers to individuals' experience (Figures 2 and 3). Over half of the subsidiaries' managers are Chinese by origin and over half have previous management experience from China. The experience from China and the Chinese market is lower for board members.

Figure 2 here.

Figure 3 here.

\section{Econometric results}

In order to test our hypothesis, we will rely on ordinary least square regressions (OLS). We start with a regression where the dependent variable is performance (PERFORM) and the explanatory variable is experience from Hong Kong, Singapore, and Taiwan (GCREXP). As seen in table 2, experience from Hong Kong, Singapore, and Taiwan, has a positive effect on performance, significant at a five percent level. The next estimation includes a number of control variables that might affect performance. As seen from model 2, experience from Hong Kong, Singapore, and Taiwan continues to positively affect performance on the Chinese market, though the coefficient is slightly less significant. Some of the control variables have a significant 
effect on performance, while others have not. For instance, it does not seem to matter for the subsidiary's performance if it is a joint venture or a wholly owned subsidiary (ENTMODE). Neither does the aggregated individual experience of the managers and board members have any significant impact on performance (INDEXP). Hence, our results suggest that firm experience seems to be more important for a subsidiary's performance than managers' and board members' individual experience. When disaggregating INDEXP into its different components and testing those separately (not shown), we found that the share of the subsidiaries' board members that are Chinese by origin has a positive and significant impact on performance, although the results was sensitive to the choice of control variables.

The type of activity affects performance. Subsidiaries conducting research and development consider themselves to be relatively successful, so does subsidiaries involved in production (RD and PROD). The significance level for production is low, but the correlation with manufacturing is high (see table A1 in the appendix) and to be engaged in manufacturing has a positive effect on performance (MANUFACT). Subsidiaries involved in marketing and sales, on the other hand, are performing comparatively worse (MS).

Output market has no significant impact on performance; it does not seem to matter if the subsidiary's products and services are sold to another unit of the firm or to another firm, nor if the products and services are sold on the Chinese market (MARKET1 and MARKET2). Neither can we detect any relationship between competition and performance (COMP1 and COMP2). This may indicate that perceived performance is a relative measure, assessed in comparison to the performance of the competitors. Finally, it does not seem like the degree to which the 
subsidiaries' activities differ from the activities of the rest of the firm has any impact on performance (DIVERSE).

We continue with three more estimations to examine the robustness of our results. The selection of variables was based on achieving high adjusted R-square values. The results remain relatively stable. Most importantly, experience from Hong Kong, Singapore, and Taiwan is positive and statistically significant in all estimations. $^{6}$

Table 2 here.

It is of interest to examine if other forms of experience, such as experience from countries outside of Greater China or from operations within China, also affect performance. One econometric problem is that our different experience variables are highly correlated (see table A1 in the appendix). The result from this multicollinearity is seen from the regressions in table 3 . All the different variables on experience are individually positive and statistically significant. However, when the different variables are included together with our variable on experience from Hong Kong, Singapore, and Taiwan, neither of the two variables are statistically significant, with the exception of the firm's history of foreign operations.

Table 3 here.

Hence, the results suggest that experience has a positive effect on performance, but multicollinearity prevents the use of regressions to analyse which type of 
experience that matters. We therefore try to further assess the significance of different experience measures by using a matrix approach where we divide the subsidiaries into four groups. We use the median values of the experience variables to separate the firms, which coincidently in the case of GCREXP equals zero.

More specifically, we start by comparing performance of firms with GCREXP = 0 and GCREXP $>0$ under the condition that the number of years a firm has had subsidiaries in China (TIMING) is less than or equal to seven years (Figure 4). The matrix can be used to answer several questions. Firstly, if experience is important for performance, we would expect performance in group 1 to be better than in group 4 . Secondly, if experience from Hong Kong, Singapore, and Taiwan is important, we would expect group 1 to show better performance than group 3 and group 2 better than group 4. Accordingly, to examine the effect of how long a firm has been present in China, we compare group 1 with group 2 and group 3 with group 4 .

Experience is important for performance as seen from a comparison of group 1 and group 4. Moreover, experience from Hong Kong, Singapore, and Taiwan improves performance as seen from a comparison of group 1 and 3 and group 2 and 4 . A long presence in China is also improving performance as seen from a comparison of group 1 and 2 and group 3 and $4 .^{7}$

Figure 4 here.

We continue in figure 5 by including experience from Hong Kong, Singapore, and Taiwan, and the number of countries the firm had subsidiaries in before they

\footnotetext{
${ }^{6}$ We tried to estimate regressions were experience from Hong Kong, Taiwan, and Singapore was treated separately. Unfortunately, the relatively small sample size prevented any useful comparison.
} 
started their operations in China. The results are less clear than in the previous matrix, but suggest that the number of countries is not a very important determinant of performance. The median value of performance is very similar in the different groups but if anything, slightly lower for firm with experience from more than 15 countries, in comparison to firms with experience from less than 15 countries. However, the difference between group 6 and 8 is significant at a five percent level. Thus, we can conclude that experience from Hong Kong, Singapore, and Taiwan has a positive effect on performance for firms with experience from relatively few countries.

Figure 5 here.

We finally compare firms with different experience from Hong Kong, Singapore, and Taiwan, and with different accumulated experience, measured in years, of international operations. Figure 6 shows firms with more experience to perform better than firms with less experience (comparison of group 9 and 12); firms with experience from Hong Kong, Singapore, and Taiwan perform better than firms without such experience (groups 9 and 11 and group 10 and 12); and firms with more than 40 years as a multinational company to perform better than firms with less than 40 years experience from international operations (groups 9 and 10 and 11 and 12).

Figure 6 here.

To sum up, the most evident result from the regressions and the matrixes is that overall experience matters for performance. By comparing performance of the groups

\footnotetext{
${ }^{7}$ Note, however, that the difference between group 2 and 4 and between group 3 and 4 is not
} 
with the most experience (left, upper) with the least experienced (right, lower), it is obvious that the more experienced firms show a significantly better performance in all three cases. It is slightly more difficult to evaluate what type of experience that matter for performance, since the variables are highly correlated. A cautious interpretation is that experience from Greater China is important and so is the number of years the firm has been a multinational company. The number of countries that the firm has subsidiaries in seems to be less important for performance.

\section{Conclusions}

Our study shows that subsidiaries of Scandinavian firms with prior experience from Hong Kong, Singapore, and Taiwan perform better on the Chinese market than subsidiaries of firms without such experience. They might do so because they are relatively fast to acquire market-specific knowledge. Market-specific knowledge is knowledge about the characteristics of a specific market: its business climate, culture, structure, and the knowledge about individual customers and their personnel. This kind of knowledge reduces uncertainty of operations and improves the performance. Market-specific knowledge is acquired through operations on the specific market. However, by having experiences from other markets in Greater China, markets that share some characteristics with the Chinese market, a firm can, due to a shorter perceived psychic distance, obtain market-specific knowledge quicker than if it should not have had this prior experience.

Because experiential market-specific knowledge is accumulated from operating on the market, we also expected to find the number of years in China to affect a 
subsidiary's performance. The expectation was confirmed; subsidiaries with a long presence in China tend to show a relatively good performance.

In addition to experience from Greater China, our study shows that general international experience matters for performance. International experience measured in years seems to be more important than the number of countries with subsidiaries. The results suggest that firms utilize knowledge acquired through running international operations, on the Chinese market. The more general knowledge a firm has accumulated, the lower the uncertainty when establishing a subsidiary in China, and the better the performance. 


\section{References}

Aharoni, Y. (1966). The Foreign Investment Decision Process. Boston, MA: Harvard Business School Press.

Bell, J. (1996). Single or joint venturing?: A Comprehensive Approach to Foreign Entry Mode choice. Avebury: Aldershot.

Björkman, I. and Eklund, M. (1996). The sequence of Operational Modes Used by Finnish Investors in Germany. Journal of International Marketing, Vol. 4, pp. ?

Black, J.S. and Mendenhall, M. (1991). The U-curve Adjustment Hypothesis Revisited: A Review and Theoretical Framework. Journal of International Business Studies, Vol. 22, No. 2., pp. 225-247.

Buckley, A. (1996). International Capital Budgeting. New Jersey: Prentice-Hall.

Carlson, S. (1975). How Foreign Is Foreign Trade? - A Problem in International Business Research. Motala: Borgströms Tryckeri.

Cavusgil, S.T. (1984). Organizational Characteristics Associated with Export Activity. Journal of Management Studies, Vol. 21, No 1, pp.3-22.

Chen, T. (1998). Taiwanese Firms in Southeast Asia - Networking Across Borders. Northampton: Edward Elgar.

Forsgren, M. (1989). Managing the Internationalization Process: The Swedish Case. London: Routledge.

Hedlund, G. and Kverneland, A. (1984), “Are Establishments and Growth Strategies for Foreign Markets Changing?: The Case of Swedish Investment in Japan”, Institute of International Business, Stockholm School of Economics.

Hood, N. and Young, S. (1983). Multinational Investment Strategies in the British Isles: A Study of MNEs in the Assisted Areas and in the Republic of Ireland. London: HMSO.

Hörnell, E. and Vahlne, J.-E. (1986). Multinationals: The Swedish Case. London: Croom Helm.

Johanson, J. and Mattsson, L.-G. (1988). Internationalisation in Industrial Systems A Network Approach. In Hood, N. and Vahlne, J.-E. (eds.), Strategies in Global Competition. New York: Croom Helm.

Johanson, J. and Vahlne, J.-E. (1977). The Internationalization Process of the Firm a Model of Knowledge Development and Increasing Foreign Market Commitments. Journal of International Business Studies, Vol. 8, pp. 23-32. 
Johanson, J. and Vahlne, J.-E. (1990). The Mechanism of Internationalisation. International Marketing Review, Vol. 4, pp. 11-24.

Kimberly, J.R. and Rottman, D.B. (1987). Environment, Organization and Effectivensss: A Biographical Approach. Journal of Management Studies, Vol. 24, No. 6, pp. 595-622.

Luo, Y. (1998). Timing of Investment and International Expansion Performance in China. Journal of International Business Studies, Vol. 29, No. 2, pp. 391-407.

Luo, Y. (1999). Dimensions of Knowledge: Comparing Asian and Western MNEs in China. Asia Pacific Journal of Management, Vol. 16, pp. 75-93.

Malhotra, N.K. (1999). Marketing Research - An Applied Orientation. New Jersey: Prentice-Hall.

March, J.G. and Olsen, J.P. (1976). Ambiguity and Choice in Organizations. Oslo: Universitetsforlaget.

Nonaka, I., Takeuchi, H., and Umemoto, K. (1996). A Theory of Organizational Knowledge Creation. International Journal of Technology Management, Vol. 11, No. 7/8, pp. 833-845.

Norwegian Trade Council Beijing (1998). Doing Business in China: Norwegian Experiences. Beijing: Norweigian Trade Council.

Norwegian Trade Council Beijing (2003). Norwegian Companies in China, www.ntcbeijing.com/ncc.htm, as of 23-04-2003.

Penrose, E.T. (1959). The Theory of the Growth of the Firm. Oxford: Basil Blackwell.

Petersen, B. and Pedersen, T. (1997). Twenty Years After - Support and Critique of the Uppsala Internalisation Model. In Björkman, I. and Forsgren, M. (eds.). The Nature of the International Firm. Copenhagen: Copenhagen Business School Press.

Royal Danish Embassy in Beijing (2003), List of Companies in China, http://www.dkembassy-cn.org/S-Business/S-B-Publications/Companies list/W.bus.complist.html, as of 2304-2003.

Sharma, D.D. (1991). International Operations of Professional Firms. Lund: Studentliteratur.

Swedish Trade Council (2002). Swedish Companies in China (2002). Beijing: Swedish Trade Council.

Swedish Trade Council (2003a). Swedish Companies in East China (2003). Beijing: Swedish Trade Council 
Swedish Trade Council (2003b). Svenska företag i östra Kina (2003). Beijing: Swedish Trade Council

Vahlne, J.-E. and Wiedersheim-Paul, F. (1977). Psychic Distance - An Inhibiting Factor in Foreign Trade. Department of Business Administration, Uppsala University, CIF Working Paper Series 1977:2.

Vahlne, J.-E. and Nordström, K. (1993). The Internationalization Process: Impact of Competition and Experience. The International Trade Journal, Vol. 7, No. 5, pp. 529548. 
Table 1

List of variables

\begin{tabular}{|c|c|c|c|c|}
\hline $\begin{array}{l}\text { Variable } \\
\text { name }\end{array}$ & Function & Type & Definition & Question \\
\hline PERFORM & Dependent & Discrete & $\begin{array}{l}\text { The average of three variables } \\
\text { measuring perceived success }\end{array}$ & $\begin{array}{l}\text { Q2: 9; } 11 ; \\
25\end{array}$ \\
\hline GCREXP & $\begin{array}{l}\text { Explanator } \\
\mathrm{y}\end{array}$ & $\begin{array}{l}\text { Logarithmic, } \\
\text { Discrete }\end{array}$ & $\begin{array}{l}\text { Number of years the firm had } \\
\text { subsidiaries in Hong Kong, Singapore, } \\
\text { and Taiwan before establishing its first } \\
\text { subsidiary in China }\end{array}$ & $\begin{array}{l}\text { Q1:5;8; } \\
9 ; 10\end{array}$ \\
\hline TIMING & $\begin{array}{l}\text { Explanator } \\
\text { y }\end{array}$ & $\begin{array}{l}\text { Logarithmic, } \\
\text { Discrete }\end{array}$ & $\begin{array}{l}\text { Number of years since the firm } \\
\text { established its first subsidiary in China }\end{array}$ & Q1: 5 \\
\hline NRCOUNT & $\begin{array}{l}\text { Explanator } \\
\mathrm{y}\end{array}$ & $\begin{array}{l}\text { Logarithmic, } \\
\text { Discrete }\end{array}$ & $\begin{array}{l}\text { Number of countries the firm had } \\
\text { subsidiaries in, before establishing its } \\
\text { first subsidiary in China }\end{array}$ & Q1: 7 \\
\hline INTYEAR & $\begin{array}{l}\text { Explanator } \\
\text { y }\end{array}$ & $\begin{array}{l}\text { Logarithmic, } \\
\text { Discrete }\end{array}$ & $\begin{array}{l}\text { Number of years the firm had } \\
\text { subsidiaries abroad before establishing } \\
\text { its first subsidiary in China }\end{array}$ & Q1:3; 5 \\
\hline ENTMODE & Control & Dummy & Joint ventures & Q2: 19 \\
\hline INDEXP & Control & $\begin{array}{l}\text { Logarithmic, } \\
\text { Discrete }\end{array}$ & $\begin{array}{l}\text { Average of eight variables measuring } \\
\text { board members' and managers' earlier } \\
\text { experiences from Hong Kong, } \\
\text { Singapore, and Taiwan }\end{array}$ & Q2: 26-33 \\
\hline MANUFACT & Control & Dummy & Manufacturing & Q2: 13 \\
\hline PROD & Control & Dummy & Production & Q2: 12 \\
\hline $\mathrm{RD}$ & Control & Dummy & Research \& Development & Q2: 12 \\
\hline MS & Control & Dummy & Marketing \& Sales & Q2: 12 \\
\hline MARKET1 & Control & Discrete & $\begin{array}{l}\text { Share of total sales sold on the Chinese } \\
\text { market. }\end{array}$ & Q2: 17 \\
\hline MARKET2 & Control & Discrete & $\begin{array}{l}\text { Share of total sales sold to other units or } \\
\text { subsidiaries of the firm. }\end{array}$ & Q2: 18 \\
\hline DIVERSE & Control & Discrete & $\begin{array}{l}\text { Degree to which the subsidiary's } \\
\text { operations differ from the firm's } \\
\text { operations. }\end{array}$ & Q2: 14 \\
\hline COMP1 & Control & Discrete & Perceived level of competition. & Q2: 15 \\
\hline COMP2 & Control & Discrete & Share of competitors present in China. & Q2: 16 \\
\hline
\end{tabular}

Note: Q1 and Q2 refer to questionnaire 1 and 2 in the appendix. 
Figure 1. Performance frequencies

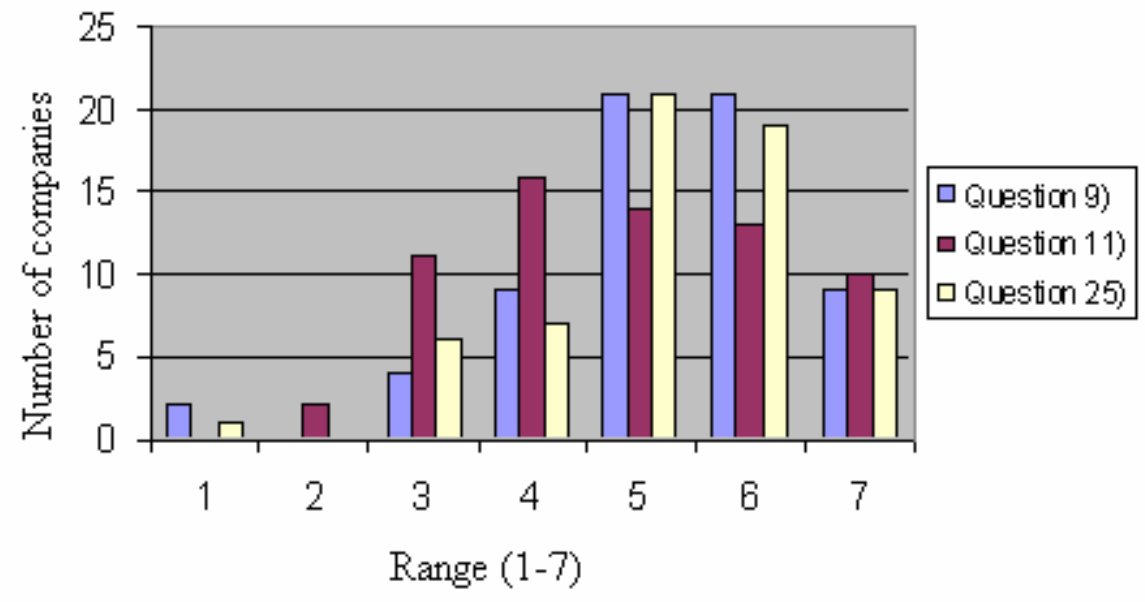

Figure 2. Background of managers

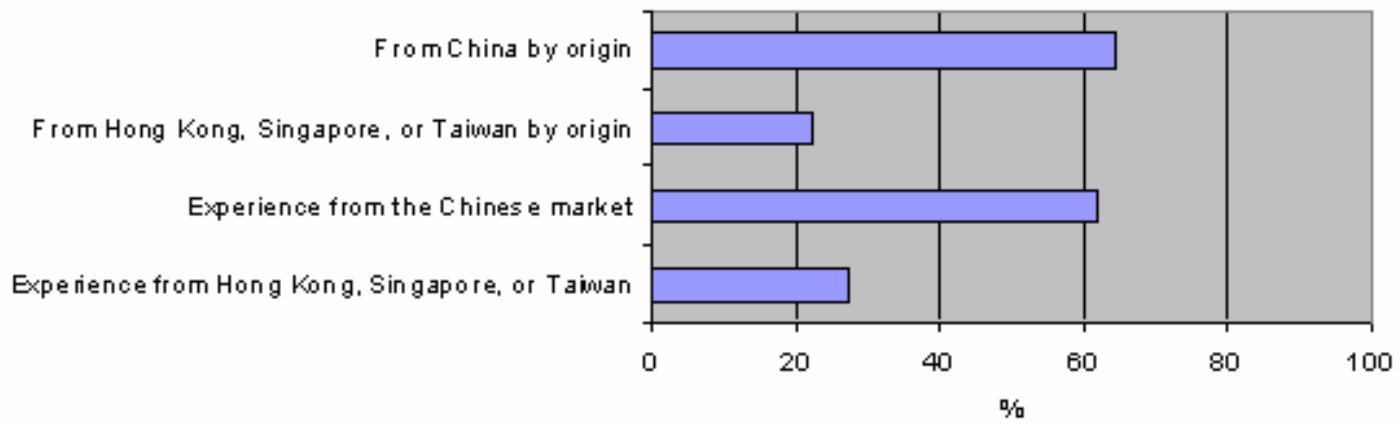

Figure 3. Background of board members

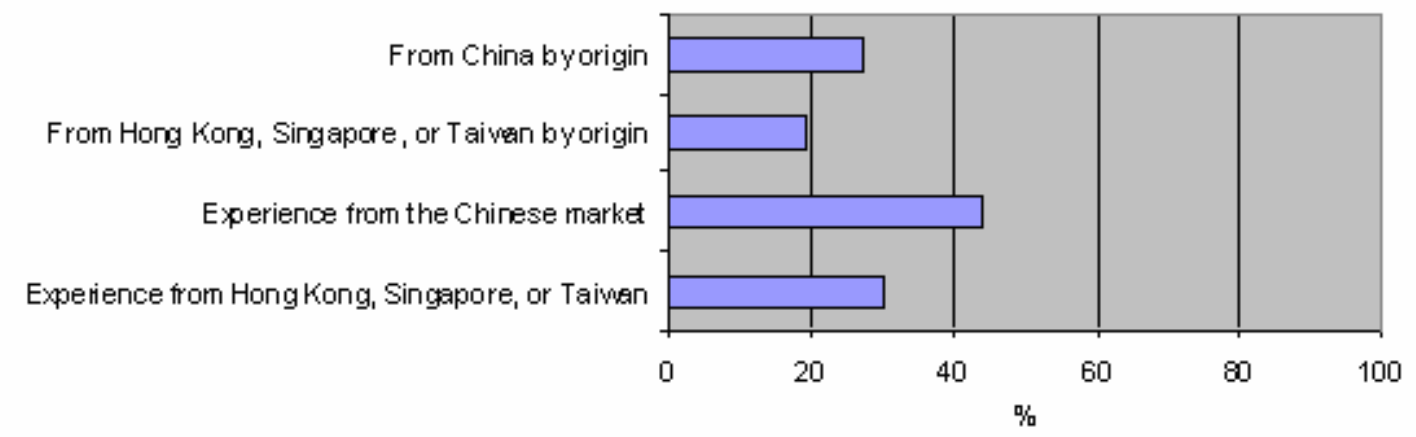


Table 2

The effect of experience on Scandinavian subsidiaries' performance in China

\begin{tabular}{|c|c|c|c|c|c|}
\hline Variables & Model 1 & Model 2 & Model 3 & Model 4 & Model 5 \\
\hline Constant & $\begin{array}{l}4.84 \\
(25.59) * *\end{array}$ & $\begin{array}{l}2.58 \\
(1.16)\end{array}$ & $\begin{array}{l}3.37 \\
(2.31)^{* *}\end{array}$ & $\begin{array}{l}4.21 \\
(9.36)^{* *}\end{array}$ & $\begin{array}{l}4.62 \\
(11.10)^{* *}\end{array}$ \\
\hline GCREXP & $\begin{array}{l}0.37 \\
(2.00)^{* *}\end{array}$ & $\begin{array}{l}0.43 \\
(0.74)^{*}\end{array}$ & $\begin{array}{l}0.34 \\
(1.92)^{*}\end{array}$ & $\begin{array}{l}0.38 \\
(2.28) * *\end{array}$ & $\begin{array}{l}0.36 \\
(2.09) * *\end{array}$ \\
\hline ENTMODE & -- & $\begin{array}{l}-0.15 \\
(-0.31)\end{array}$ & -- & -- & -- \\
\hline INDEXP & -- & $\begin{array}{l}0.31 \\
(0.21)\end{array}$ & $\begin{array}{l}-0.14 \\
(-0.13) \\
\end{array}$ & -- & -- \\
\hline MANUF. & -- & $\begin{array}{l}0.77 \\
(1.99) *\end{array}$ & $\begin{array}{l}0.77 \\
(2.13) * *\end{array}$ & $\begin{array}{l}0.54 \\
(1.72)^{*}\end{array}$ & $\begin{array}{l}0.66 \\
(2.07)^{* *}\end{array}$ \\
\hline PROD & -- & $\begin{array}{l}0.43 \\
(1.12)\end{array}$ & $\begin{array}{l}0.36 \\
(1.03)\end{array}$ & -- & -- \\
\hline $\mathrm{RD}$ & -- & $\begin{array}{l}0.98 \\
(2.64)^{* *}\end{array}$ & $\begin{array}{l}0.94 \\
(2.83) * *\end{array}$ & $\begin{array}{l}0.87 \\
(2.67)^{* *}\end{array}$ & $\begin{array}{l}0.81 \\
(2.42)^{* *}\end{array}$ \\
\hline $\mathrm{MS}$ & -- & $\begin{array}{l}-0.96 \\
(-2.19)^{* *}\end{array}$ & $\begin{array}{l}-0.85 \\
(-2.21)^{* *}\end{array}$ & $\begin{array}{l}-0.79 \\
(-2.16)^{* *}\end{array}$ & $\begin{array}{l}-0.53 \\
(-1.50) \\
\end{array}$ \\
\hline MARKET1 & -- & $\begin{array}{l}-0.01 \\
(-0.07)\end{array}$ & -- & -- & -- \\
\hline MARKET2 & -- & $\begin{array}{l}0.13 \\
(1.32)\end{array}$ & $\begin{array}{l}0.13 \\
(1.67)\end{array}$ & $\begin{array}{l}0.15 \\
(2.14)^{* *}\end{array}$ & -- \\
\hline DIVERSE & -- & $\begin{array}{l}0.11 \\
(0.99)\end{array}$ & $\begin{array}{l}0.11 \\
(1.08)\end{array}$ & -- & -- \\
\hline COMP1 & -- & $\begin{array}{l}0.12 \\
(0.95)\end{array}$ & -- & -- & -- \\
\hline COMP2 & -- & $\begin{array}{l}-0.09 \\
(-0.81) \\
\end{array}$ & -- & -- & -- \\
\hline R-square & 0.06 & 0.39 & 0.37 & 0.28 & 0.22 \\
\hline Adj. R-sq. & 0.04 & 0.23 & 0.27 & 0.22 & 0.17 \\
\hline No. of obs. & 65 & 57 & 58 & 65 & 65 \\
\hline
\end{tabular}

Note: t-statistics within brackets. ${ }^{*}$, significant at the 1 percent level, ${ }^{* *}$ significant at the 5 percent level, $* * *$ - significant at the 1 percent level. 
Table 3

Different types of experience and Scandinavian subsidiaries performance in China

\begin{tabular}{|l|l|l|l|l|l|l|}
\hline Variable & Model 6 & Model 7 & Model 8 & Model 9 & Model 10 & Model 11 \\
\hline Constant & $\begin{array}{l}4.29 \\
(9.02)^{* *}\end{array}$ & $\begin{array}{l}4.43 \\
(9.13)^{* *}\end{array}$ & $\begin{array}{l}4.45 \\
(14.61)^{* *}\end{array}$ & $\begin{array}{l}4.49 \\
(14.54)^{* *}\end{array}$ & $\begin{array}{l}3.85 \\
(10.70)^{* *}\end{array}$ & $\begin{array}{l}3.81 \\
(10.00)^{* *}\end{array}$ \\
\hline GCREXP & -- & $\begin{array}{l}0.28 \\
(1.30)\end{array}$ & -- & $\begin{array}{l}0.18 \\
(0.78)\end{array}$ & -- & -0.01 \\
& & $\begin{array}{l}0.53 \\
(0.90)\end{array}$ & -- & -- & -- & -- \\
\hline TIMING & 0.92 & & & - & \\
& $(1.77)^{*}$ & -- & 0.55 & 0.42 & -- & -- \\
\hline NRCOUNT & -- & $(2.36)^{* *}$ & $(1.45)$ & - & 0.92 \\
\hline INTYEAR & -- & -- & -- & -- & $(3.72)^{* *}$ & $\begin{array}{l}1.01 \\
(3.03)^{* *}\end{array}$ \\
\hline R-square & 0.05 & 0.07 & 0.08 & 0.09 & 0.20 & 0.20 \\
\hline Adj. R-sq. & 0.03 & 0.04 & 0.07 & 0.06 & 0.18 & 0.17 \\
\hline No. of obs. & 64 & 64 & 65 & 65 & 58 & 58 \\
\hline
\end{tabular}

Note: t-statistics within brackets. ${ }^{*}$, significant at the 1 percent level, $* *$ significant at the 5 percent level, $* * *$ - significant at the 1 percent level. 
Figure 4. Matrix for GCREXP and TIMING

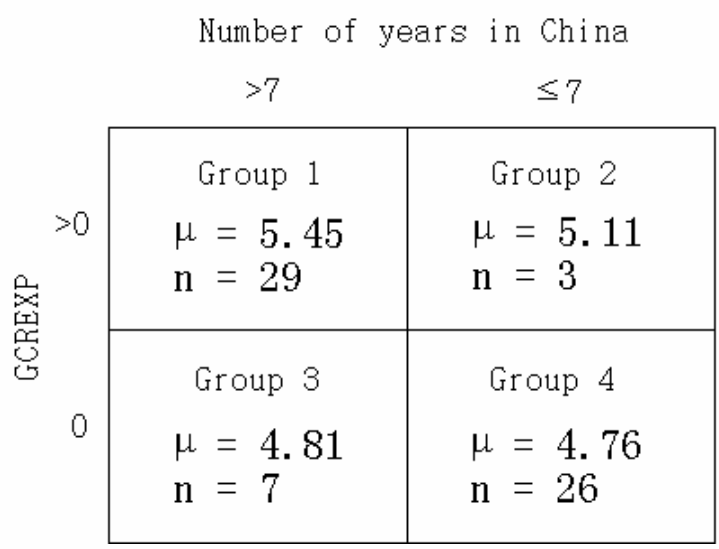

Figure 5. Matrix for GCREXP and NRCOUNT

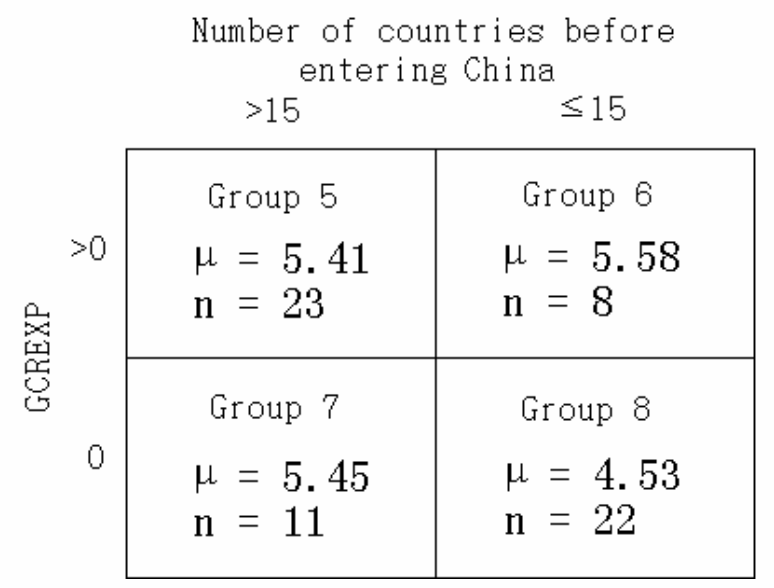

Figure 6. Matrix for GCREXP and INTYEAR

\begin{tabular}{|c|c|c|}
\hline & $>40$ & $\leq 40$ \\
\hline$>0$ & $\begin{array}{l}\text { Group } 9 \\
\mu=5.56 \\
\mathbf{n}=23\end{array}$ & $\begin{array}{l}\text { Group } 10 \\
\mu=4.94 \\
\mathrm{n}=6\end{array}$ \\
\hline 0 & $\begin{array}{l}\text { Group } 11 \\
\mu=5.33 \\
\mathbf{n}=6\end{array}$ & $\begin{array}{l}\text { Group } 12 \\
\mu=4.57 \\
\mathrm{n}=24\end{array}$ \\
\hline
\end{tabular}




\section{Appendix}

Table A1

Correlation Matrix

\begin{tabular}{|c|c|c|c|c|c|c|c|c|}
\hline & GCREXP & TIMING & NRCOUNT & INTYEAR & ENTMODE & INDEXP & MANUFACT & PROD \\
\hline GCREXP & 1 & $0,49^{* *}$ & $0,59^{\star *}$ & $0,66^{\star \star}$ & $0,37^{* *}$ & 0,17 & $-0,05$ & $-0,09$ \\
\hline TIMING & $0,49^{\star \star}$ & 1 & $0,42^{\star \star}$ & $0,45^{\star \star}$ & 0,04 & 0,12 & 0,11 & $-0,24^{*}$ \\
\hline NRCOUNT & $0,59^{\star *}$ & $0,42^{\star \star}$ & 1 & $0,77^{\star *}$ & $0,28^{\star *}$ & 0,21 & 0,04 & $0,22^{*}$ \\
\hline INTYEAR & $0,66^{\star *}$ & $0,45^{\star \star}$ & $0,77^{\star *}$ & 1 & $0,29^{\star *}$ & 0,19 & $0,25^{*}$ & 0,10 \\
\hline ENTMODE & $0,37^{\star *}$ & 0,04 & $0,28^{\star *}$ & $0,29^{\star \star}$ & 1 & $0,58^{\star *}$ & $0,25^{\star \star}$ & $0,23^{*}$ \\
\hline INDEXP & 0,17 & 0,12 & 0,21 & 0,19 & $0,58^{\star \star}$ & 1 & 0,19 & 0,08 \\
\hline MANUFACT & $-0,05$ & 0,11 & 0,04 & $0,25^{\star}$ & $0,25^{\star \star}$ & 0,19 & 1 & 0,19 \\
\hline PROD & $-0,09$ & $-0,24^{*}$ & $0,22^{*}$ & 0,10 & $0,23^{*}$ & 0,08 & 0,19 & 1 \\
\hline RD & 0,07 & 0,07 & 0,00 & 0,12 & $-0,06$ & 0,14 & 0,09 & 0,05 \\
\hline MS & 0,01 & $-0,01$ & 0,03 & 0,11 & 0,01 & 0,18 & 0,05 & $-0,02$ \\
\hline MARKET1 & $0,34^{\star *}$ & $0,23^{*}$ & 0,04 & 0,09 & $-0,03$ & $-0,16$ & $-0,04$ & $-0,04$ \\
\hline MARKET2 & $-0,07$ & 0,03 & 0,10 & 0,13 & 0,09 & $0,35^{\star \star}$ & 0,18 & 0,07 \\
\hline DIVERSE & 0,02 & $-0,07$ & $0,23^{*}$ & 0,02 & 0,04 & $-0,04$ & $-0,04$ & 0,15 \\
\hline coMP1 & $-0,01$ & 0,02 & $-0,20$ & $-0,13$ & 0,03 & 0,03 & $-0,05$ & $-0,11$ \\
\hline COMP2 & $0,23^{*}$ & $0,30^{\star *}$ & 0,12 & $0,26^{\star *}$ & 0,14 & $0,23^{*}$ & $-0,03$ & $-0,03$ \\
\hline \multirow[t]{2}{*}{ PERFORM } & $0,24^{\star *}$ & $0,22^{*}$ & $0,28^{\star *}$ & $0,44^{\star \star}$ & 0,10 & 0,14 & $0,24^{*}$ & 0,09 \\
\hline & RD & MS & MARKET1 & MARKET2 & DIVERSE & COMP1 & COMP2 & PERFORM \\
\hline GCREXP & 0,07 & 0,01 & $0,34^{* *}$ & $-0,07$ & 0,02 & $-0,01$ & $0,23^{*}$ & $0,24^{\star *}$ \\
\hline TIMING & 0,07 & $-0,01$ & $0,23^{*}$ & 0,03 & $-0,07$ & 0,02 & $0,30^{\star *}$ & $0,22^{*}$ \\
\hline NRCOUNT & 0,00 & 0,03 & 0,04 & 0,10 & $0,23^{*}$ & $-0,20$ & 0,12 & $0,28^{\star *}$ \\
\hline INTYEAR & 0,12 & 0,11 & 0,09 & 0,13 & 0,02 & $-0,13$ & $0,26^{\star *}$ & $0,44^{\star *}$ \\
\hline ENTMODE & $-0,06$ & 0,01 & $-0,03$ & 0,09 & 0,04 & 0,03 & 0,14 & 0,10 \\
\hline INDEXP & 0,14 & 0,18 & $-0,16$ & $0,35^{\star \star}$ & $-0,04$ & 0,03 & $0,23^{*}$ & 0,14 \\
\hline MANUFACT & 0,09 & 0,05 & $-0,04$ & 0,18 & $-0,04$ & $-0,05$ & $-0,03$ & $0,24^{*}$ \\
\hline PROD & 0,05 & $-0,02$ & $-0,04$ & 0,07 & 0,15 & $-0,11$ & $-0,03$ & 0,09 \\
\hline RD & 1 & 0,02 & 0,18 & $-0,07$ & 0,09 & $-0,20$ & 0,00 & $0,31^{* *}$ \\
\hline MS & 0,02 & 1 & $-0,29^{\star *}$ & $0,33^{* *}$ & $-0,12$ & 0,08 & $-0,06$ & $-0,15$ \\
\hline MARKET1 & 0,18 & $-0,29^{\star *}$ & 1 & $-0,59^{\star *}$ & $-0,31^{* *}$ & $-0,17$ & $-0,05$ & 0,07 \\
\hline MARKET2 & $-0,07$ & $0,33^{\star *}$ & $-0,59^{* *}$ & 1 & 0,15 & 0,05 & 0,09 & 0,17 \\
\hline DIVERSE & 0,09 & $-0,12$ & $-0,31^{\star *}$ & 0,15 & 1 & $-0,04$ & 0,12 & 0,13 \\
\hline coMP1 & $-0,20$ & 0,08 & $-0,17$ & 0,05 & $-0,04$ & 1 & $0,29^{\star *}$ & 0,01 \\
\hline COMP2 & 0,00 & $-0,06$ & $-0,05$ & 0,09 & 0,12 & $0,29^{\star *}$ & 1 & 0,09 \\
\hline PERFORM & $0,31^{\star \star}$ & $-0,15$ & 0,07 & 0,17 & 0,13 & 0,01 & 0,09 & 1 \\
\hline
\end{tabular}

Note: $\left.{ }^{*}\right)$ Significant at the five percent level; *) Significant at the ten percent level. 
Questionnaire 1

\section{Definitions}

With the company, we refer to the parent company of the group.

With Mainland China, we refer to the People's Republic of China (excluding Hong Kong, Macao, and Taiwan).

The survey

1. What is the main industry of the company?

2. In how many countries, excluding the home country, does the company have subsidiaries or joint ventures today?

3. In what year did the company first start up subsidiaries or joint ventures abroad?

4. In what country did the company first start up subsidiaries or joint ventures outside the home country of the company?

5. In what year did the company start up subsidiaries or joint ventures in Mainland China?

6. In what city did the company first start up subsidiaries or joint ventures in Mainland China?

7. In how many countries did the company have subsidiaries or joint ventures before starting up in Mainland China?

8. Does the company have subsidiaries or joint ventures in Hong Kong? If yes, in what year did the company start up its first subsidiary or joint venture in Hong Kong?

9. Does the company have subsidiaries or joint ventures in Taiwan? If yes, in what year did the company start up its first subsidiary or joint venture in Taiwan?

10. Does the company have subsidiaries or joint ventures in Singapore? If yes, in what year did the company start up its first subsidiary or joint venture in Singapore?

11. Your name:

Your position within the company:

Phone number: 


\section{Questionnaire 2}

\section{Definitions - please read this carefully before filling in the questionnaire}

1. With "subsidiary", we refer to the Chinese legal entity (joint venture or wholly owned foreign entel to which this survey was sent, including its respective subsidiaries and joint ventures.

PLEASE NOTE: If your parent company has established more than one subsidiary in China, please on answer in respect to your own specific subsidiary.

2. With "start-up", we refer to the founding of the subsidiary in China.

3. With "China", we refer to the People's Republic of China, excluding Hong Kong, Macao and Taiwan

Part 1: Growth and Performance of the Chinese Subsidiary

A) Number of Employees

1. The number of employees is higher today than one year ago.

$\square$ True $\square$ False $\square$ No answer

2. The number of employees is higher today than in any previous year.

$\square$ True $\square$ False $\square$ No answer

\section{B) Annual Sales}

3. Annual sales in 2002 were higher than they were in 2001.

$\square$ True $\square$ False $\square$ No answer

4. Annual sales in 2002 were higher than in any previous year.

口True $\square$ False $\square$ No answer

\section{C) Return on Equity}
5. Return on equity in 2002 was higher than in 2001.
$\square$ True $\quad \square$ False $\quad$ 口No answer
6. Return on equity in 2002 was higher than in any previous year.
$\square$ True $\square$ False $\square$ No answer
7. The subsidiary had a positive return on equity for 2002 .
$\square$ True $\square$ False $\square$ No answer
8. The subsidiary had a positive return on equity within three years from starमupe $\quad \square$ False $\quad \square$ No answer

\section{D) Own Perception}

9. How successful do you consider the subsidiary to be?

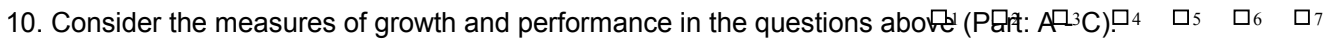
How well do these measures reflect your own perception of the subsidiary's (1=not at all, $7=$ very well)

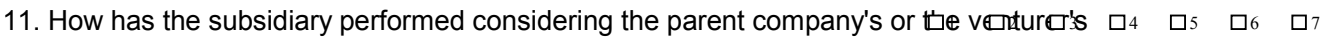
expectations before start-up?

( $1=$ worse than expected, $7=$ better than expected) 
Part 2: Operations of the Chinese Subsidiary

\section{A) Activities}

12. What type of activities are carried out in the subsidiary? (More than one alterqative is possible)

$\square$ Research and Development

$\square$ Marketing and Sales

$\square$ Other, Please specify:

13. In what industry(ies) does the subsidiary operate? (More than one alternativeuilorpassibleledstry

$$
\begin{aligned}
& \square \text { Fishing } \\
& \square \text { Mineral extraction } \\
& \square \text { Manufacturing } \\
& \square \text { Electricity-, gas-, water supply } \\
& \square \text { Construction } \\
& \square \text { Hotel-, restaurant service } \\
& \square \text { Transportation, communication } \\
& \square \text { Financial services } \\
& \square \text { Property- and letting operations } \\
& \square \text { Other company services } \\
& \square \text { Education } \\
& \square \text { Health-, medical-, social services } \\
& \square \text { Other public- or personal services } \\
& \square \text { Other, Please specify: }
\end{aligned}
$$

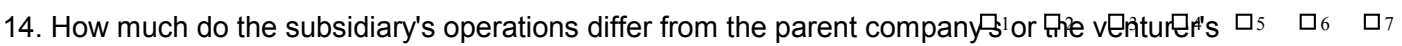
operations?

\section{B) Competition}

15. To what degree is the subsidiary exposed to competition?

$$
\square_{1} \quad \square_{2} \quad \square_{3} \quad \square_{4} \quad \square_{5} \quad \square_{6} \quad \square_{7}
$$$$
\text { ( } 1 \text { = very low, } 7 \text { = very high) }
$$

16. Of the total number of main competitors to the parent company, how maロy ara $2 \quad \square 3 \quad \square 4 \quad \square 5 \quad \square 6 \quad \square 7$ present in China today through representative offices, subsidiaries or joint $\mathrm{v}(1=$ none, $7=$ all $)$

\section{C) Market}

17. How much of the subsidiary's total sales is sold to other subsidiaries, joir $\square$ verᄆuareş $3 \quad \square 4 \quad \square 5 \quad \square 6 \quad \square 7$ business units or divisions of the parent company or the venturer/s? $\quad(1=$ nothing, $7=$ all $)$

18. How much of the subsidiary's total sales is sold to on the Chinese retail nark $\square^{2} \quad \square 3 \quad \square 4 \quad \square 5 \quad \square 6 \quad$ व7 (or to China-based enterprises)?

( $1=$ nothing, $7=$ all $)$ 
Part 3: Characteristics of the Subsidiary

\section{A) Ownership}

19. The subsidiary is a joint venture. (If false, please continue to question nuhriber 22) $\square$ False

20. At least one of the venturers is a Chinese enterprise.

口True $\quad$ 口False

21. When starting up, regulations required one of the venturers to be a Chincsenenterpise:

\section{B) Characteristics}

22. What is the amount of total assets according to the closing balance of 2 USD

23. What was the amount of total sales in 2002 ? USD

24. What is the current total number of employees?

25. Over all, are you satisfied with the performance of the subsidiary?

$\square_{1} \quad \square_{2} \quad \square_{3} \quad \square_{4} \quad \square_{5} \quad \square_{6} \quad \square_{7}$

\section{Part 4: Experience}

26. How many of the subsidiary's board members are from China by origin? $\square_{1} \quad \square_{2} \quad \square_{3} \quad \square_{4} \quad \square_{5} \quad \square_{6} \quad \square_{7}$ ( $1=$ none, $4=$ half, $7=$ all $)$

27. How many of the subsidiary's board members are from Hong Kong, Taiv $\square$ an o $\square$ Singapo $\square 4 \quad \square 5 \quad \square 6 \quad \square 7$ by origin?

( $1=$ none, $4=$ half, $7=$ all $)$

28. How many of the subsidiary's board members have previous experiencefrombanegeneent $\square 5$ in a company in China? $\quad(1=$ none, $4=$ half, $7=$ all $)$

29. How many of the subsidiary's board members have previous experiencefromøanagencent $\square 5$ in a company in Hong Kong, Taiwan or Singapore? $\quad(1=$ none, $4=$ half, $7=$ all $)$

30. How many of the subsidiary's managers are from China by origin? $\quad \square_{1} \quad \square_{2} \quad \square_{3} \quad \square_{4} \quad \square 5 \quad \square 6 \quad \square 7$ ( 1 = none, $4=$ half, 7 = all)

31. How many of the subsidiary's managers are from Hong Kong, Taiwan orळßing by origin? $\quad(1=$ none, $4=$ half, $7=$ all $)$

32. How many of the subsidiary's managers have previous experience from $\square$ lanagyemnnt $\quad \square 4 \quad \square 5$ in a company in China?

( $1=$ none, $4=$ half, $7=$ all $)$

33. How many of the subsidiary's managers have previous experience from Phlanagenchent $_{4} \quad \square \quad \square 5 \quad \square 6 \quad \square 7$ in a company in Hong Kong, Taiwan or Singapore? $\quad(1=$ none, $4=$ half, $7=$ all $)$ 